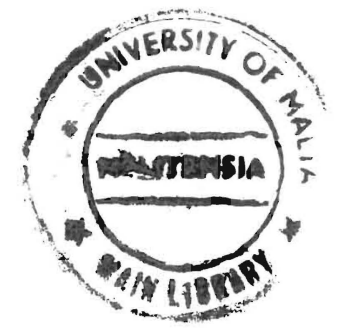

\title{
Tectonics of the Maltese Islands
}

\author{
C. D. REUTHER
}

Geologisches Institut, Universität Karlsruhe, Kaiserstrasse, 12, 6500 Karlsruhe Fed. Rep. of Germany.

(Received 16th November 1983)

\begin{abstract}
The Maltese Islands are a key area in the Central Mediterranean for understanding the development of faulting and foreland reactions on the northern edge of the African plate. Convergent and lateral motions along the Afro-Eurasian plate boundary generated different and superimposed stress regimes in the sedimentary cover, which governed the fracture pattern and fault processes.
\end{abstract}

Structural evolution of the Maltese Islands:

(1) Lower Miocene: Synsedimentary NE-SW $\left(50-70^{\circ}\right)$ trending extension fractures developed.

(2) Upper Tortonian: Synsedimentary normal faults, trending $150^{\circ}$, reflect the first tectonic impulse in the formation of the Pantelleria Rift (W of Malta) which interrupts in a NW-SE direction the shelf bridge that connects northern Africa with southern Sicily.

(3) Post Tortonian-Lower Messinian and pre Quaternary: NE-SW to ENE-WSW (60 $-80^{\circ}$ ) trending horsts and grabens which traverse the islands were formed. At the same time the Pantelleria Rift evolved with its climax in the Pliocene. The contemporaneousness of both events might be due to a mantle updoming which hit pre-existent crossing weakness zones in the overlying crust.

(4) Quaternary-recent: Normal faulting orientated $120^{\circ}$ and associated with the Pantelleria Rift. Continuous rifting leads to ongoing shoulder unwarping, with Maltese Islands tilting towards NE.

Some of the NE-SW trending normal faults are neotectonally remodelled into 
strike slip faults. The kinematic analysis of the fracture pattern on E-Gozo results in a general model for a shear process within an interstratification of competent and incompetent rocks.

\section{Introduction}

The Maltese Islands are situated in the Strait of Sicily between Italy and North Africa. The distance to the southern coast of Sicily is about $90 \mathrm{~km}$ and to the eastern Tunisian coast about $300 \mathrm{~km}$. The archipelago has a length of $45 \mathrm{~km}$ with Malta as the largest island in the south $\left(246 \mathrm{~km}^{2}\right)$ and the island of Gozo $\left(67 \mathrm{~km}^{2}\right)$ in the north. Between Malta and Gozo, separated by the $1 \mathrm{~km}$ wide North Comino, and the $2 \mathrm{~km}$ wide South Comino Channel are the islets of Comino and Cominotto with a total area of $2.5 \mathrm{~km}^{2} .4 .5 \mathrm{~km}$ off the southern coast of Malta lies Filfla Island, only some hundred square metres in size (Fig. 1).

The Maltese Islands, which rise up to $253 \mathrm{~m}$ above sea level, form an emerged part on the southern upwarped NE-shoulder of the Pantelleria Rift which interrupts the shallow shelf platform connecting Europe and Africa (Illies 1981). The fracture pattern of the islands has been created by tectonic processes governed by the relative motions between the European and African plates. The plate boundary runs about 200 to $400 \mathrm{~km}$ to the north of Malta from Tunisia to Sicily (Fig. 11).

Maltese strata and structures were first described by Spratt (1854) and Hobbs (1914). Further data on the geology were given by Hyde (1955). An excellent base for detailed studies on Maltese rock succession and tectonics is presented in the Geological Map of Malta (1:31 680) by the BRITISH PETROLEUM Co. Ltd. (1957). Additional data on the stratigraphy and structures were given by House et al. (1961), Felix (1973), Pedley et al. (1976), Pedley \& Waugh (1976), Zammit-Maempel (1977) and Pedley et al. (1978). The analysis of the complex joint pattern of the islands was one of the main aspects in the geological, structural and geomorphological study of Vossmerbäumer (1972). The first kinematic interpretations of Maltese tectonics have been carried out by Illies (1980, 1981).

The Maltese strata comprise hard, massive sometimes reefal, tectonically competent coralline limestones, ductile fine grained biomicrites and plastic marls and clays of a tectonically incompetent behaviour. The litho- and chronostratigraphical rock succession and the paleoenvironment of the Maltese Islands have been studied in detail by Murray (1890), Felix (1973), Pedley (1978), Pedley et al. (1978), Di Geronimo et al. (1981). According to these authors they consists of the following formations:

- Upper Coralline Limestone Formation: up to $162 \mathrm{~m}$ thick, represented by shallow water facies ranging from subtidal through intertidal and supratidal environments.

- Greensand Formation: up to $12 \mathrm{~m}$ glauconitic limestones.

- Blue clay Formation: up to $65 \mathrm{~m}$ slightly consolidated marls which have been deposited in an open marine environment at sea-depth between 200 and $40 \mathrm{~m}$.

- Globigerina Limestone Formation: a 23 - $207 \mathrm{~m}$ thick sequence of fine-grained biomicrites with intercalated layers of phosphorite nodules. These series have been deposited at water depth between 40 and $150 \mathrm{~m}$ in a shallow shelf area.

- Lower Coralline Limestone Formation: exposed above sea level up to $140 \mathrm{~m}$, represented by a shallow water facies formed at sea-depth of less than $50 \mathrm{~m}$. 


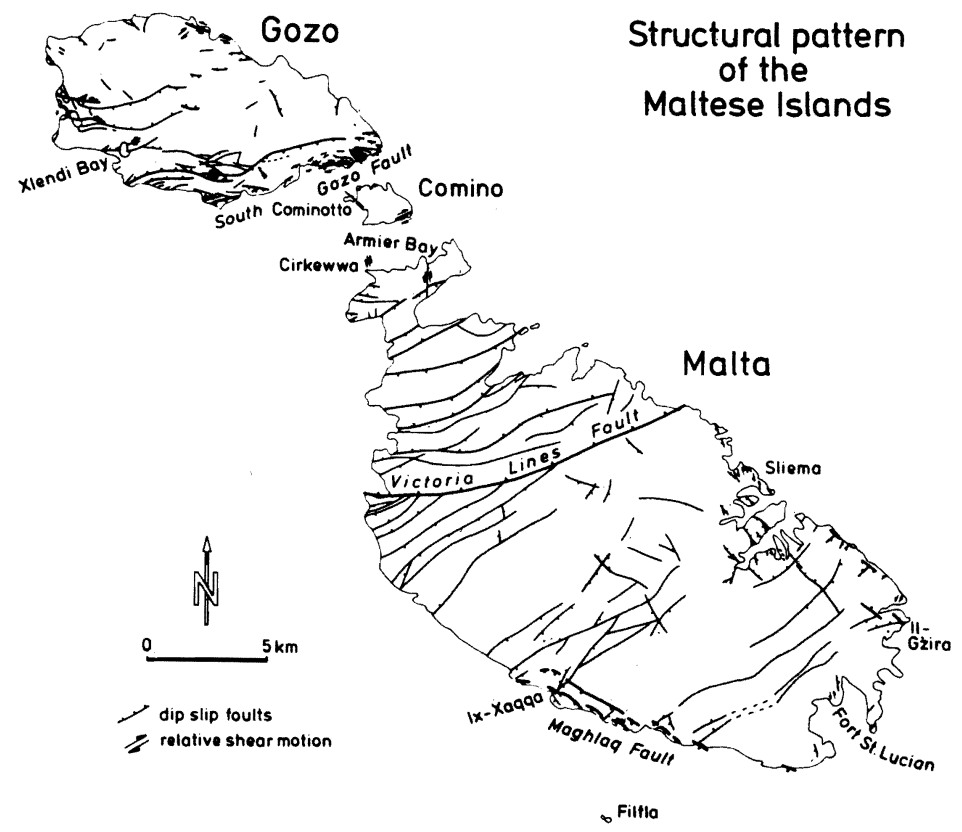

Fig. 1. Structural pattern of the Maltese Islands (modified after BP Geological Map 1957, House et al. 1961, Pedley \& Waugh 1976 and Illies 1982)

After Felix (1973) the Lower Coralline Limestone corresponds to the Chattian stage of the Upper Oligocene and the overlying strata to the Aquitanian through to Tortonian age. Giannelli \& Salvatorini (1975) proposed a Messinian age for the Upper Coralline Limestone Formation and Di Geronimo et al. (1981) considered a Langhian to Tortonian age for the Blue Clay Formation. Pedley (1983) supposes that during the Lower Messinian, oscillations of the sea level have produced erosion surfaces within the Upper Coralline Limestone Formation. No strata of Pliocene age is known so far from the Maltese Islands. Quaternary deposits are restricted to isolated patches of paleosoils, fluvial gravels, alluvial fans, dunes and infillings of fissures.

\section{Evolution of Maltese fault tectonics}

The fracture pattern of the Maltese Islands is governed by two intersecting fault systems which alternate in tectonic activity. A NE-SW to ENE-WSW trending fault system traverses the islands and is crossed by a NW-SE trending fault system (Fig. 1) parallel to the Malta trough, the easternmost graben of the Pantelleria-Rift System.

The oldest tectonic movements observable on the Maltese Islands are synsedimentary NE-SW trending extension features formed during the deposition of the 


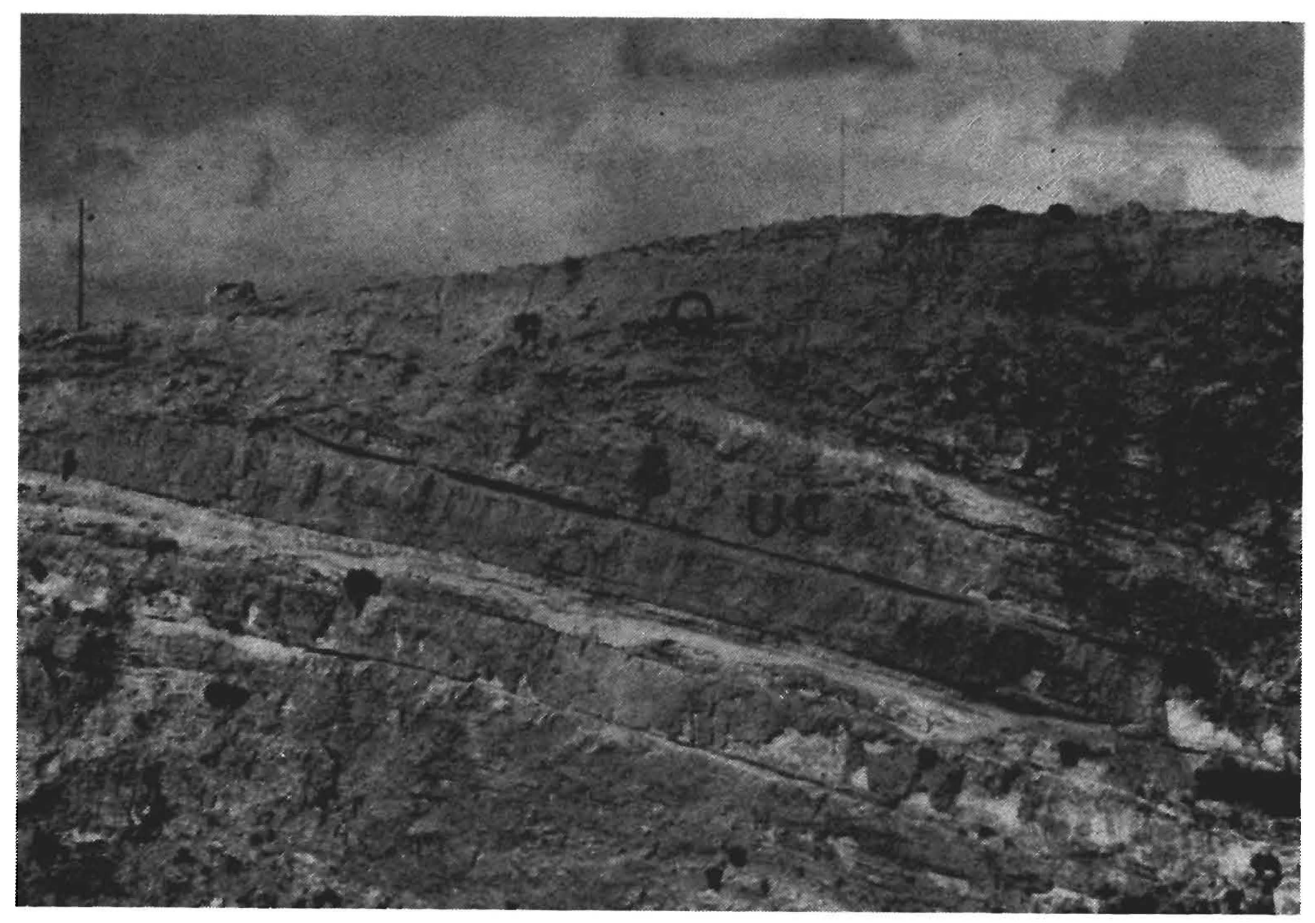

Fig. 2. Unconformity between Quaternary deposits $(\mathrm{Q})$ and the Upper Coralline Limestone Formation (UC) on West Malta at Fomm-ir-Rih Bay north of Victoria Lines Fault.

Globigerina Limestone Formation. These structures were interpreted first by Illies (1980) who described growth faulting with a trend of $55^{\circ}$, south of Xlendi Bay on Gozo. These synsedimentary movements took place before the deposition of the first main phosphorite layer which marks the top of the Lower Globigerina Limestone Formation and corresponds to the Aquitanian/Burdigalian boundary (Felix 1973). Sedimentary dikes in the Lower Globigerina Limestone infilled with material of the phosphorite layer and trending parallel to the growth fault, as observed by Illies (1980) on Gozo, are also developed in southern Malta, e.g. near Il-Gzira where they trend $70^{\circ}$. The decrease in thickness of the Lower Globigerina Limestone towards the Comino Channels (Pedley et al. 1976) is caused, according to Illies $(1980,1981)$, by a slight regional syndepositional rift uparching which preceded the formation of the NE-SW trending basin-and-range structure between the Victoria Lines Fault on central Malta and the South Gozo Fault. Parallel to these faults growth faulting affected as well the basal part of the Upper Coralline Limestone Formation (Bosence \& Pedley 1982). The main dip-slip events forming the NE-SW trending horsts and grabens, which are also topographically very well pronounced, took place after the deposition of the Upper Coralline Limestone Formation. The throw along the northward dipping Victoria Lines Fault reaches $183 \mathrm{~m}$ on the west coast of Malta and decreases towards the east coast to about $90 \mathrm{~m}$ (House et al. 1961). The vertical displacement of the South Gozo Fault, dipping southwards, is about $100 \mathrm{~m}$. This graben generation, traceable to the Aquitanian, became extinct before the Quaternary (Illies 1980, 1981). No vertical displacements of Quaternary deposits at this fault generation are known on the islands; 
rather the fault scarps are unconformably capped by Pleistocene sediments (Fig. 2). However, during the sedimentation of the Upper Coralline Limestone Formation, NW-SE trending normal faulting had occurred already and this is interpreted to be connected with the initial movements of the Pantelleria Rift System. In the Upper Coralline Limestone, for example, south of Ix-Xaqqa at the southern coast of Malta, a yellowish limestone layer, about $80 \mathrm{~cm}$ thick, reveals $150^{\circ}$ trending step faulting (Fig. 3). These vertical displacements decrease into the overlying sediments. The yellowish layer rests upon an up to $1 \mathrm{~m}$ thick concretionary limestone horizon, which according to Zammit-Maempel (1977), marks the base of the uppermost division in the Upper Coralline Limestone Formation (Lower Messinian, Pedley 1983). Upper Messinian sediments are lacking on the Maltese Islands. Strong vertical displacements in the upper Miocene related to the Pantelleria Rift are indicated in the Upper Messinian graben fillings of the Malta and Linosa troughs which consists of calcarenites bearing an oligotypic pelagic fauna (Colantoni \& Borsetti 1973). The main subsidence lasted through Pliocene (Finetti \& Morelli 1973), and some faults of the Pantelleria Rift are considered to be active up to present times.

Faults on the Maltese Islands associated with the Pantelleria Rift are represented by the NW-SE trend. The most prominent young tectonic feature is the system of the Magflaq Fault (Pedley \& Waugh 1976) SE of Ix-Xaqqa along the southern coast of Malta with a vertical displacement of at least $240 \mathrm{~m}$ to the SW (House et al. 1962). The $120^{\circ}$ trending fault shows neotectonic activity. An interstratification of red soil, breccia and caliche at Ras il-Bajjada ( $3 \mathrm{~km} \mathrm{SE}$ of Ix-Xaqqa) is cut by the fault and slickensided (Fig. 4). At Ix-Xaqqa young sediments of probably Quaternarian age are smeared

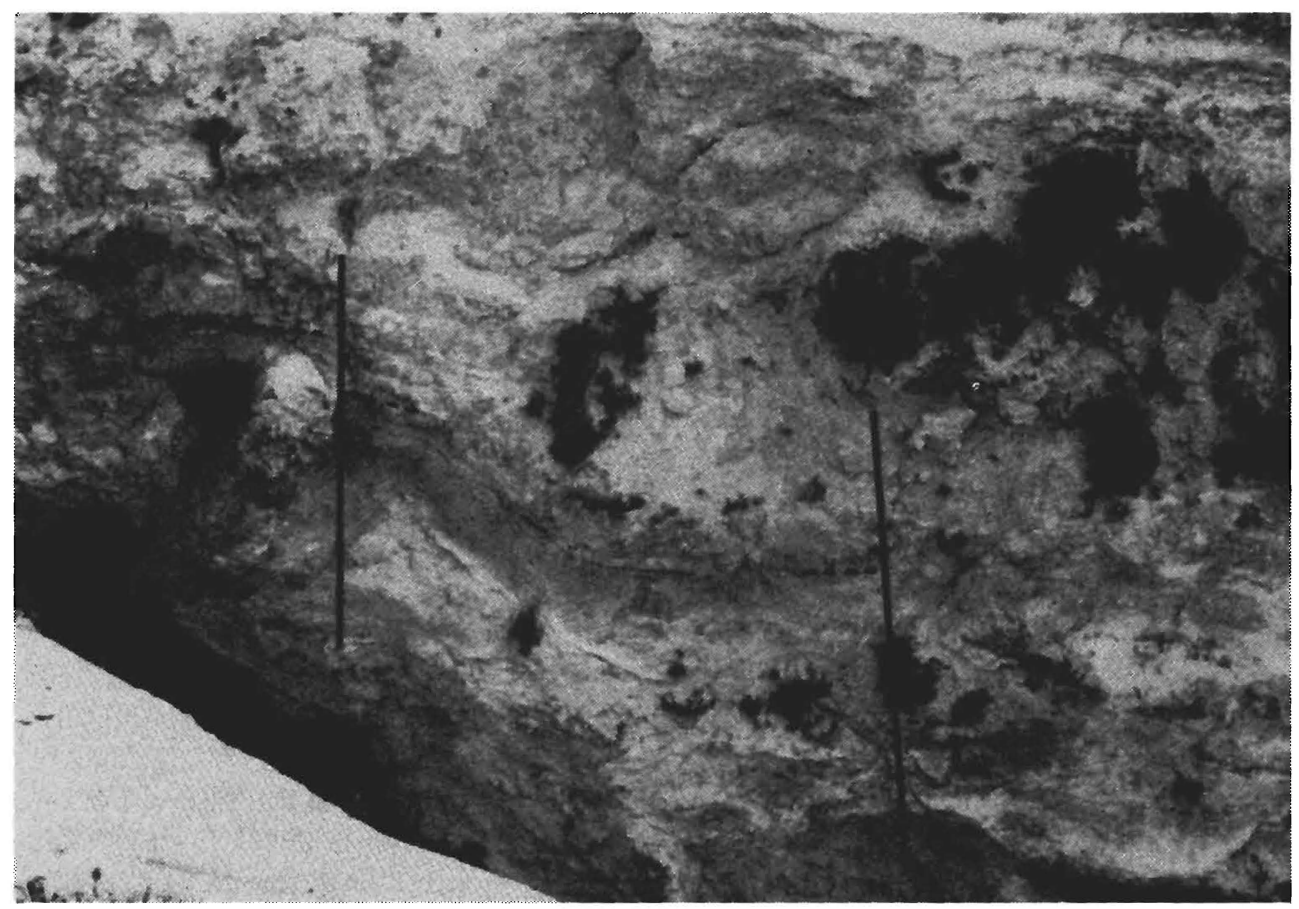

Fig. 3. Synsedimentary $150^{\circ}$ trending faults in the upper part of the middle Upper Coralline Limestone Formation at Ix-Xaqqa. 


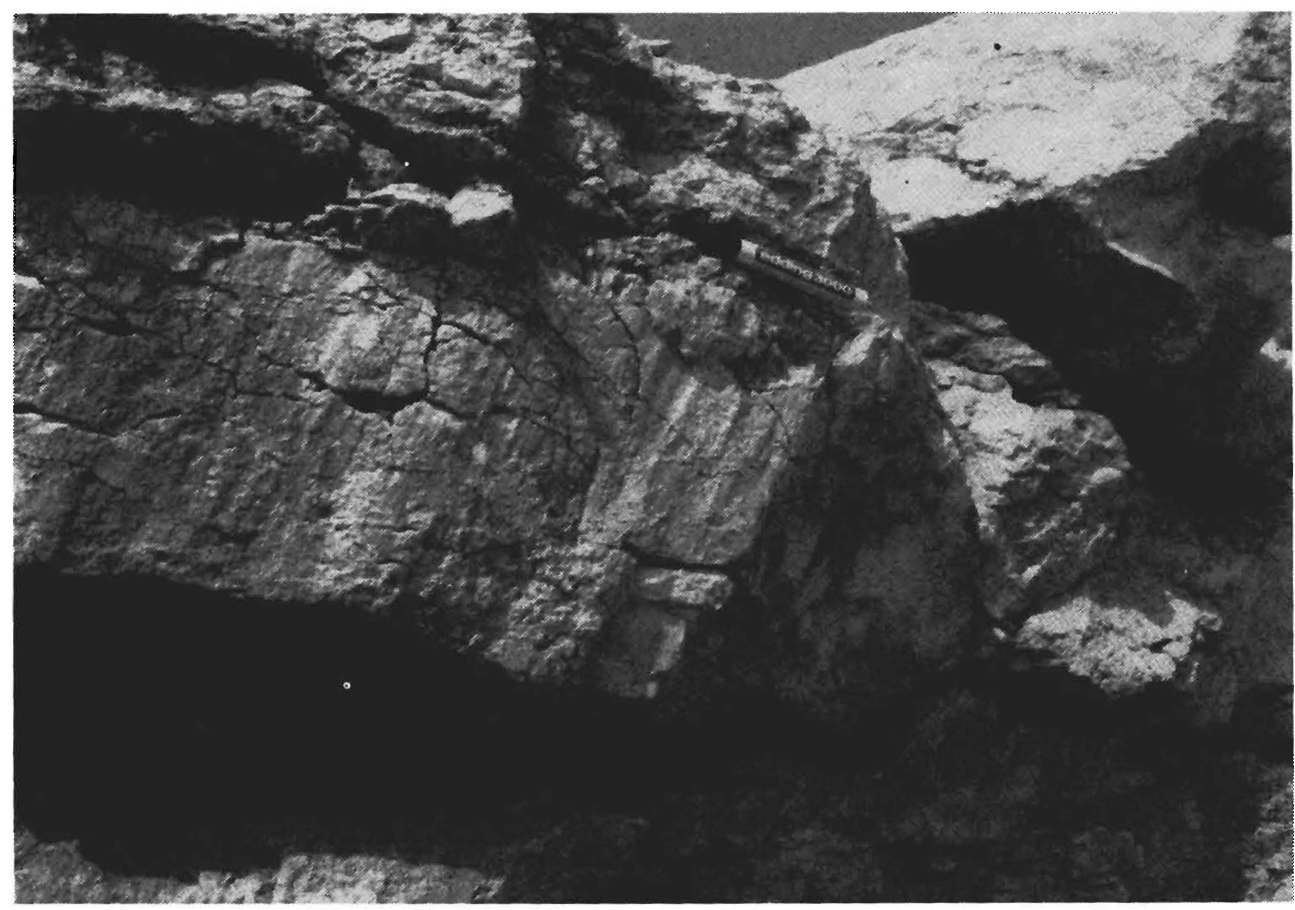

Fig. 4. Neotectonic $120^{\circ}$ trending dip slip fault plane with vertical slickensides of the Maghlaq fault system $3 \mathrm{~km}$ SE of Ix-Xaqqa at the southern coast of Malta.

in the fault plane. Quaternary and post Quaternary tectonics along the Maghlaq fault have also been mentioned by Trechmann (1938) and Illies (1980, 1981). The NW-SE trending faults crosscut and displace the previous structures (Illies 1980, 1981; Reuther 1983b). This is to be observed in Central Malta and along the southern and northern coast of SE-Malta. A very expressive exposure showing the displacement of a $70^{\circ}$ striking normal fault along two $135^{\circ}$ trending normal faults, is to be seen in the Globigerina Limestone at Il-Gzira on the eastern coast of Malta (Fig. 5).

Besides normal faulting the Maltese Islands have also been affected by horizontal movements. This is indicated at many sites by the formation of second order tension and-shear fractures. These staggered arranged features specify the relative sense of strike slip movements. The second order shear structures visible in the Globigerina Limestone at the northern coast of Malta in the Sliema region can be interpreted to be related to sinistral strike slip movements trending between $140^{\circ}$ and $160^{\circ}$. The shear structures are exposed in the vicinity of $120 / 50 \mathrm{SW}$ orientated normal faults. The tension joints in the Globigerina Limestone near Fort St. Lucian in SW-Malta described by Vossmerbäumer (1972) might be related to the same NNW-SSE trend of shear motion. Second order faulting at Cirkewwa on N-Malta in the Upper Coralline Limestone reveals also sinistral strike slip motion but with a NNE-SSW trend. Parallel to this trend horizontal slickensides occur in the Upper Coralline Limestone near Armier Bay/N-Malta (Vossmerbäumer 1972). Small scale shear structures are very well developed in the Lower Globigerina Limestone on the northern coast of 


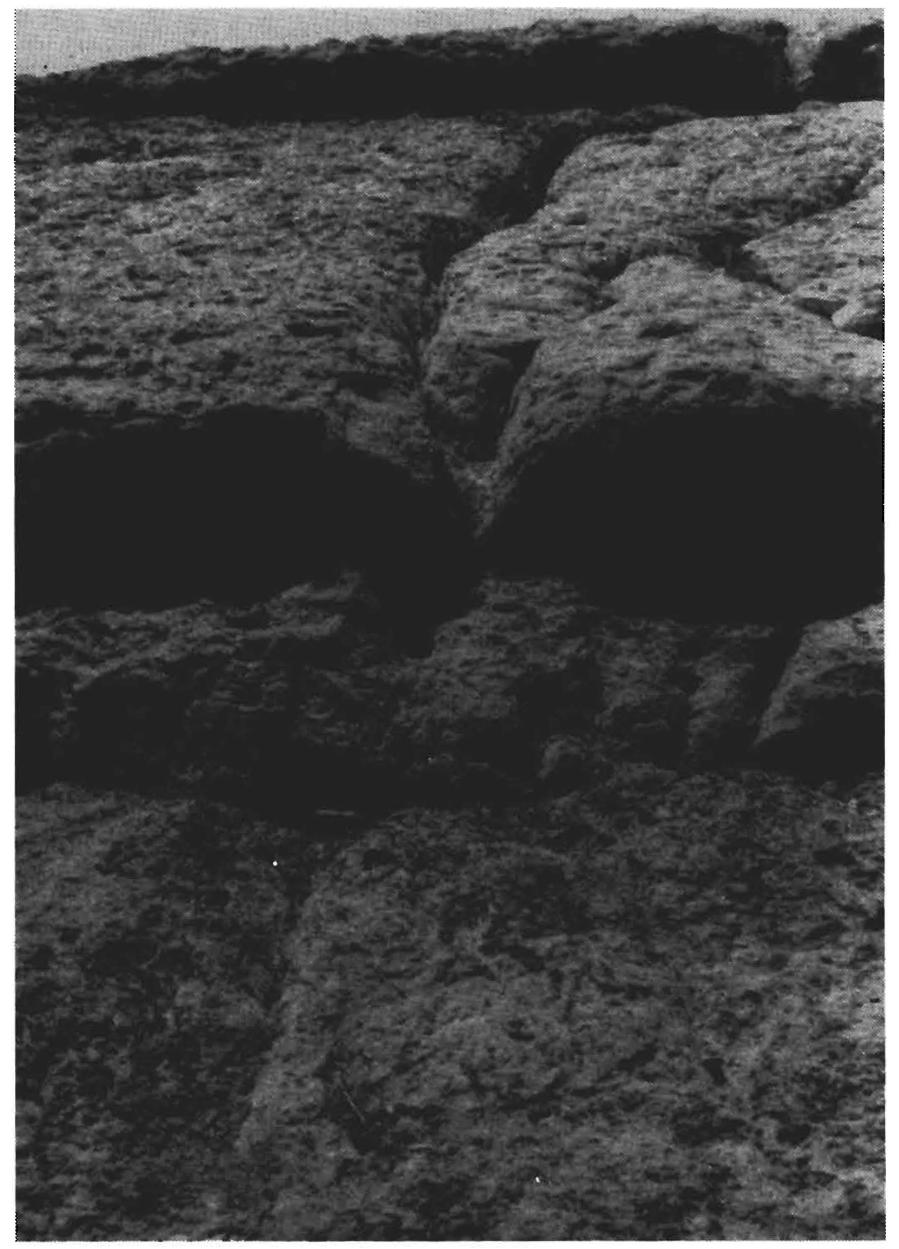

Fig. 5. Vertical displacements of a $70^{\circ}$ trending dip slip fault along two parallel $135^{\circ}$ trending dip slip faults in the Globigerina Limestone at Il-Gzira.

Gozo. In general the NE-SW shear direction is of dextral polarity while the NW-SE direction is of sinistral polarity. In western Gozo, subcircular intra-Tertiary subsidence structures (Pedley 1974) with diameters up to $500 \mathrm{~m}$ are crossed by strike slip and oblique slip faults which displace the margins up to $50 \mathrm{~m}$. Illies (1980) refers this kind of shear to be controlled by the regional stress regime, gravitational sliding towards the subsidence structures and/or the superposition of both these processes. The most spectacular shear structure of the Maltese Islands is exposed on East Gozo where a dextral strike slip motion trending $90^{\circ}$ to $65^{\circ}$ has created a large scale en echelon structure (Illies 1980, 1981; Reuther, 1983c). 


\section{Formation of large scale Feather within Feather Structures on East Gozo}

The block faulted area of east Gozo (Fig. 6) has been formed by the superimposition of two tectonic processes, different in relative fault displacement and in age. The South Gozo Fault originated as a normal fault and forms the northern master fault of the horst and graben system traversing the Maltese Islands. The dip slip fault has been remodelled into a dextral strike slip fault. On the fault plane horizontal slickensides are observed to overprint vertical slickensides. Illies $(1980,1981)$ attributed the dextral motions and its resulting first and second order shear structures on east Gozo and northwest Malta (Fig. 1) to transform faults of the Pantelleria Rift which trace a preexistent weakeness zone in the Comino Channels.

The excellent exposures on east Gozo enable a "three-dimensional" mapping of shear structures within an interstratification of competent and incompetent rocks. So the temporal state of formation, succession and interaction of tension and shear fractures related to a strike slip fault could be reconstructed step by step.

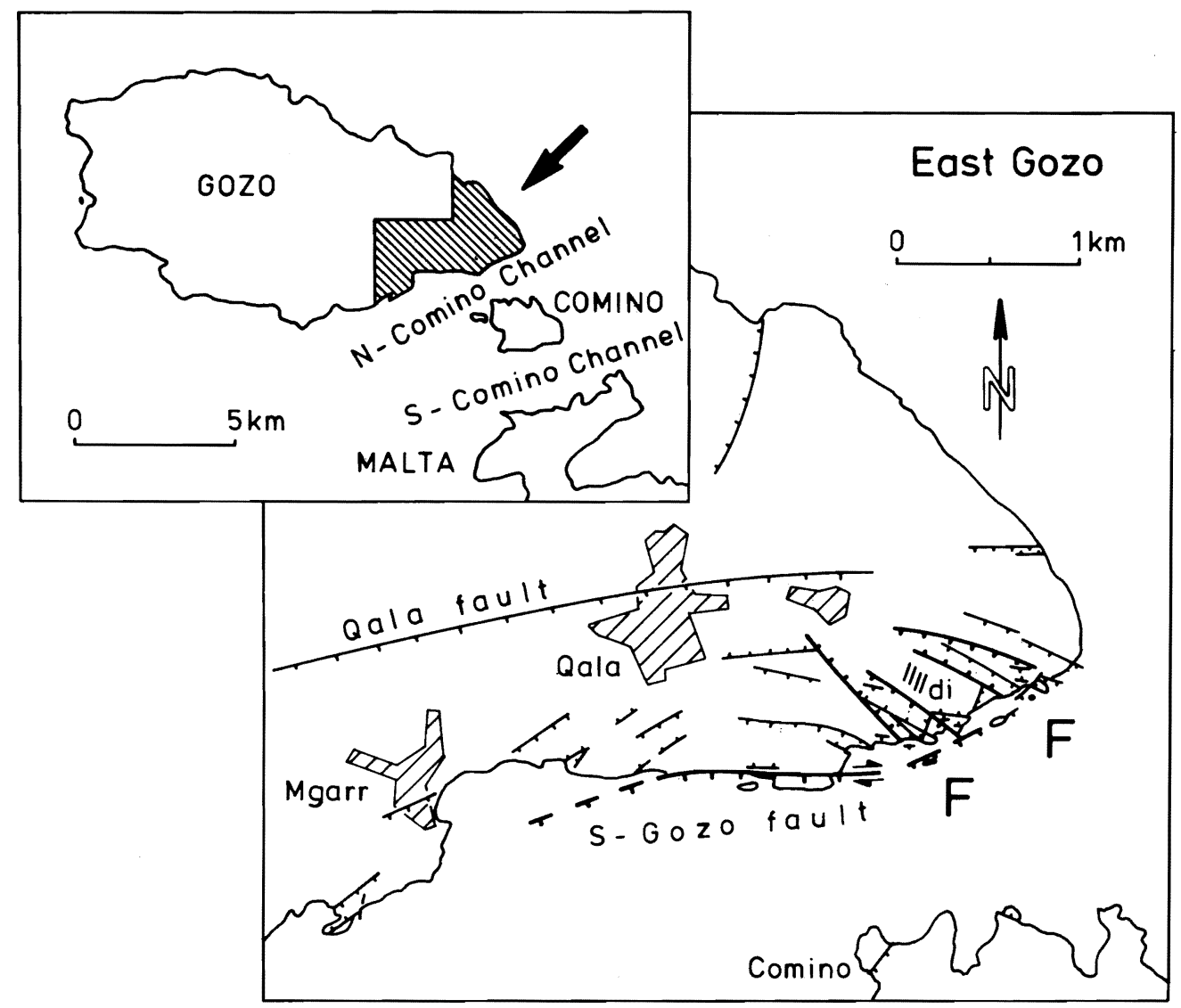

Fig. 6. Structural map of east Gozo: S-Gozo fault and Qala fault as well as some parallel faults in between developed as normal faults. During a later tectonic stage the S-Gozo fault has been remodelled into a dextral strike-slip fault. As a consequence of the strike slip motions large scale feather within feather structures $(\mathrm{F})$ have been formed oblique to the S-Gozo fault. 


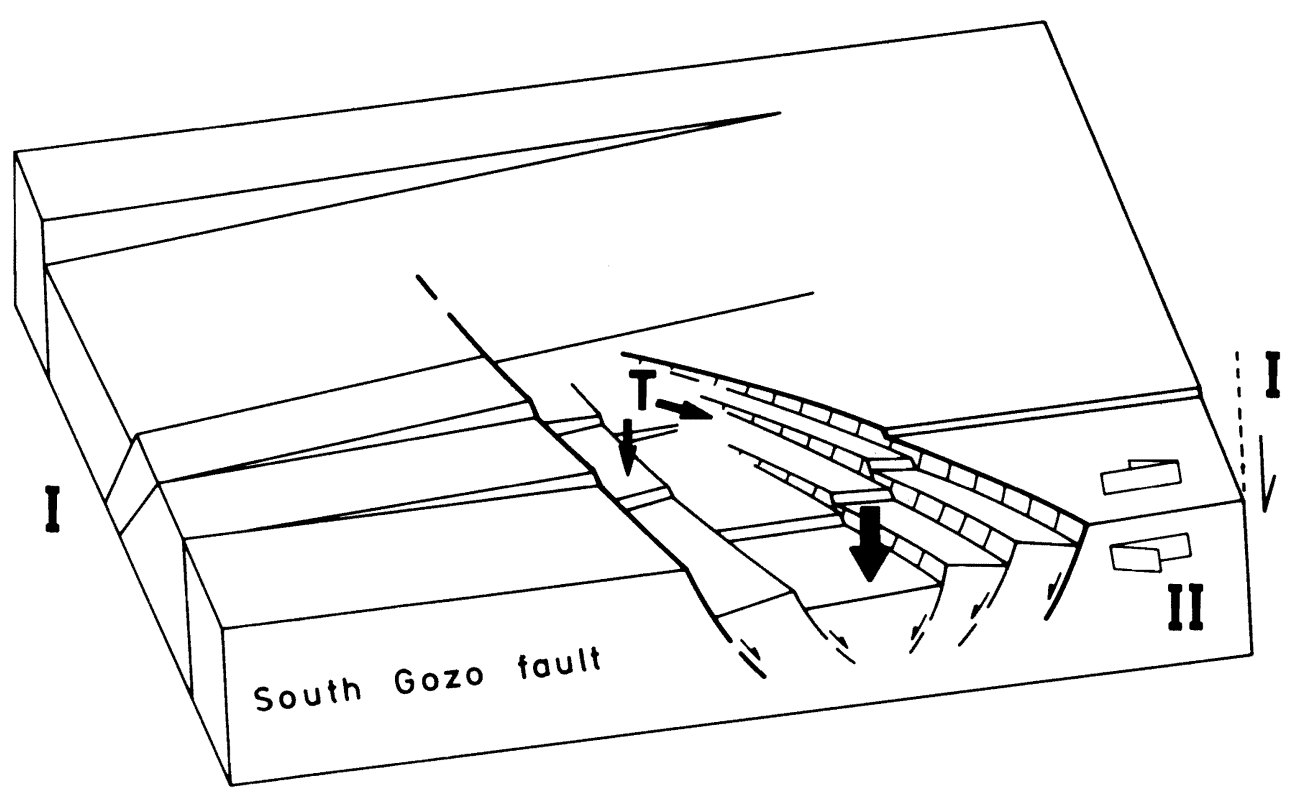

Fig. 7. Large scale feather structures $700 \times 250 \mathrm{~m}$. Tension $(\mathrm{T})$ and subsidence (black arrows) increase towards the S-Gozo fault (I: first tectonic stage of normal faulting, II: second tectonic stage with dextral strike slip along the S-Gozo fault). The feather structure crosses and displaces the previous (I) structures.

As a consequence of the dextral motion, large scale tension gashes or feather structures have been formed ( $F$ in Fig. 6). These structures crosscut and displace the previously developed normal faults parallel to the South Gozo fault. The highest amount of extension within the feather structures is along the dextral strike-slip master fault. Due to this opening of the feather structures, the vertical displacement (black arrows in Fig. 7) along the individual tension faults increases towards the strike-slip master fault. The incompetent Globigerina Limestone and its overlying rock succession became downwarped into the Lower Coralline Limestone (Fig. 8). The maximal vertical displacement observed in the feather structure amounts to $50 \mathrm{~m}$ near the dextral master fault. In the field one can follow the outcropping curved hinge faults up to the outer end of the mega fissure where the vertical displacement is only a few centimeters within one layer of the Upper Coralline Lst. Form. The feather structures on east Gozo are exposed up to a length of $700 \mathrm{~m}$ and a width of $250 \mathrm{~m}$. They form an angle of $55^{\circ}$ to $70^{\circ}$ with the dextral master fault. Continuous shear has led to a rotation of these initial feather structures until no further extension was possible. Outside the mega fissures, in the Lower Coralline Limestone, dextral strike-slip faults are to be recognized forming a more plane angle with the master fault. They are interpreted as Riedelshears (Riedel 1929). These Riedelshears cut off and displace previous large tension gashes (Reuther 1983b). Within the large scale feather structure in the downwarped incompetent rock, fault planes are observable with oblique slickensides. These faults are interpreted as rotated Riedelshears which have got a tensional component during the ongoing shear process. Additionally to horizontal mega shear lense rotations up to $20^{\circ}$ between the Riedelshears, subsidence between the rotated 


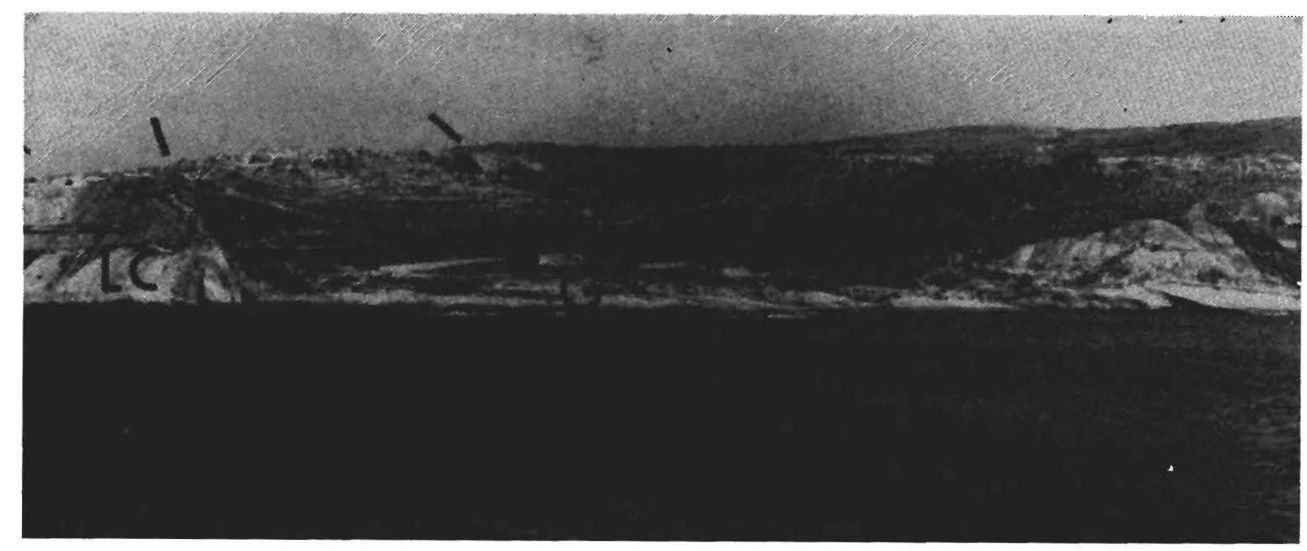

Fig. 8. View of large scale feather structure on the southern coast of E-Gozo. Globigerina Limestone $(\mathrm{G})$ and Blue Clay (B) have been downwarped inte the Lower Coralline Limestone (LC).

Riedelshears finally also occurred. Second feather structures hảve been formed $\left(\mathrm{F}^{\prime}\right.$ in Fig. 9) inside the initial feather structures ( $F$ in Fig. 6) and have created a feather within feather structure (Reuther 1983a). The faults forming the $\mathrm{F}^{\prime}$ structure die out towards the outer hinge faults of the initial F structure. The schematic block diagram of Fig. 9 is based on geological field mapping on a scale 1:2500.

Vertical displacement along rotated Riedelshears is also to be observed along Riedelshears with a length of 1 to $3 \mathrm{~m}$ in several places on Gozo (Reuther 1983c). This corresponds to the widened shear joints in Riedel's experiment (Riedel 1929).

Near the South Gozo fault a lateral extension of about $11 \%$ has been calculated for the total structure. The extension has led to internal tilt-block rotations. Some blocks of Upper Coralline Limestone are inclined $30^{\circ}$ (a in Fig. 10). Due to the intersection of the $\mathrm{F}$ and $\mathrm{F}^{\prime}$ structures some blocks became totally isolated (Fig. 9) and have tilted arbitrarily (b in Fig. 10).

In the Upper Coralline Limestone Formation a dense pattern of calcite veins is to be recognized (di in Fig. 6). These fractures might be interpreted as conjugate Riedel elements (Illies 1981). In general these microfaults show extension rather than horizontal offset. Measurement of the joint spaces result in a total dilatancy of $2.5 \%$ related to a $250 \mathrm{~m}$ long territorial section.

Neotectonic movements affecting the feather within feather structures during or after Quaternary times might be indicated in slickensided brown-reddish infillings of fissures in the Lower Coralline Limestone in the easternmost part of Gozo (see also Hyde, $\mathrm{p}$. 59). Minimal, probably post Bronze aged, offset is implied in sinistral bending of the ancient cart tracks which cross on a length of about $200 \mathrm{~m}$ the above mentioned microfaults corresponding to the conjugate Riedelshears of the shear zone.

The detailed structural mapping of east Gozo leads to the conclusion that during the shear process, tension fractures occurred at first. These tension fractures have been pierced during further shear by shear fractures which have also widened due to continous shear motion. The individual large scale shear structures correspond in geometry and succession to one of Riedel's clay experiments (Riedel 1929). 


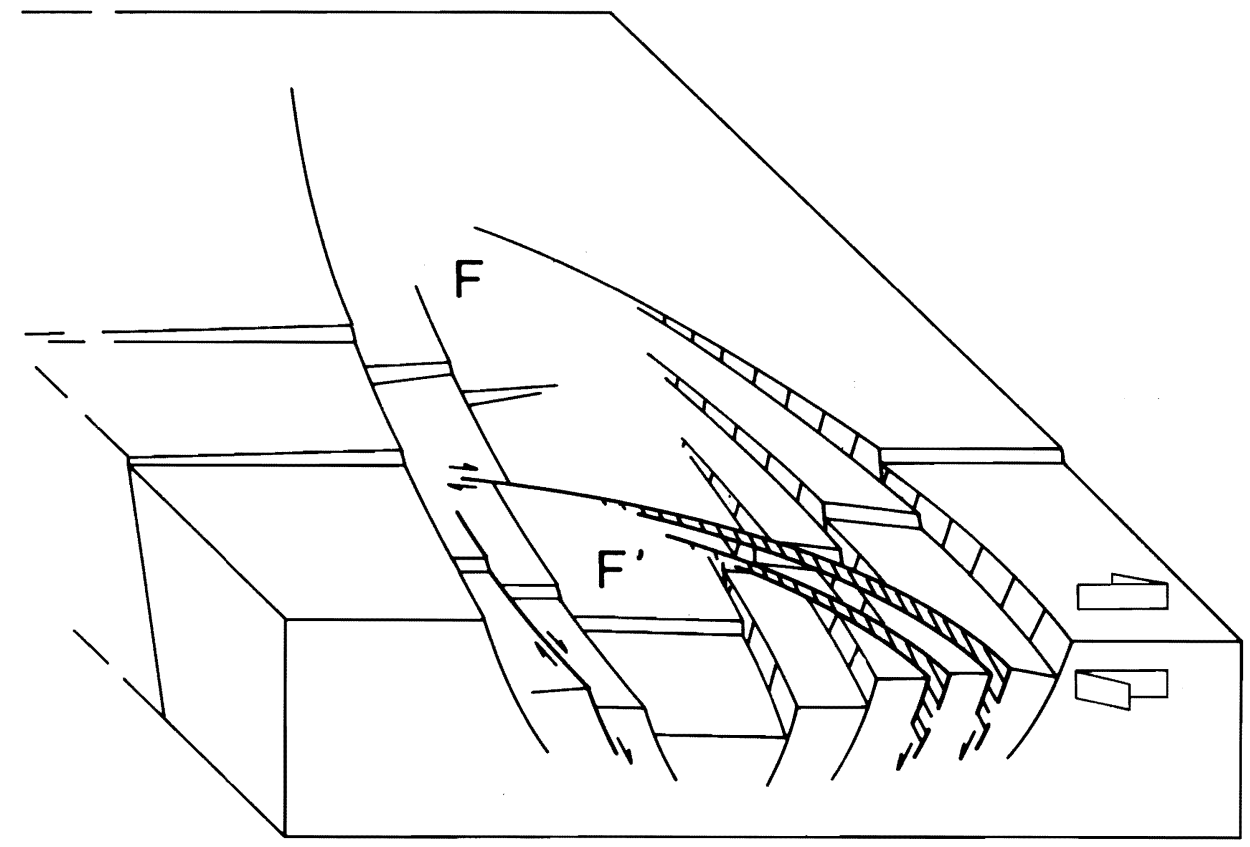

Fig. 9. Feather-within-feather structure: Within the rotated initial feather structure $(F)$ a second feather structure $\left(F^{\prime}\right)$ has developed, formed by rotated and widened Riedelshears (up to $450 \mathrm{~m}$ long), caused by a continuous shear process.

\section{Structural Setting of the Maltese Islands in the Strait of Sicily- Central Mediterranean Sea}

In terms of plate tectonics the Maltese Islands belong to the African plate and are an emerged segment, on the shallow shelf bridge of the Strait of Sicily, of the Pelagian Sea that connects the Ragusa plateau of southern Sicily with the Tunisian plateau (Morelli et al. 1975, Burollet et al. 1978, Finetti 1982). The Afro-Eurasian plate boundary is marked by an active seismic belt which runs from the Azores across Gibraltar and North Africa to northern Sicily (McKenzie 1970, 1972). The tectonic evolution on the plate margins has been controlled since the Upper Triassic through to present times by the relative motions between Africa (Gondwana) and Europe (Eurasia) (Smith 1971, Smith \& Woodcock 1982). From the Upper Triassic to the Upper Cretaceous the African plate moved south-eastwards revealing a sinistral megashear movement along the plate boundary. During this time span the northern edge of the African plate was governed by extensional tectonics and meanwhile oceanic crust was produced between the diverging African and European plates (Barberi et al. 1974). Compressional continental collision, affecting a wide deformation zone, set in during the Upper Cretaceous. Palaeo-stress field determinations of Letouzey \& Trémolières (1980) in Tunisia show an average stress orientation of $140^{\circ}$ in Upper Cretaceous rocks, and $160^{\circ}$ in Eocene rocks, which should also have affected the Strait of Sicily. During Late Oligocene and Early Miocene NE-SW palaeo-stress orientations have been observed all around the central Mediterranean (Letouzey \& Trémolières 1980). The oldest extensional features on Malta in the Globigerina Limestone Formation have the same trend 


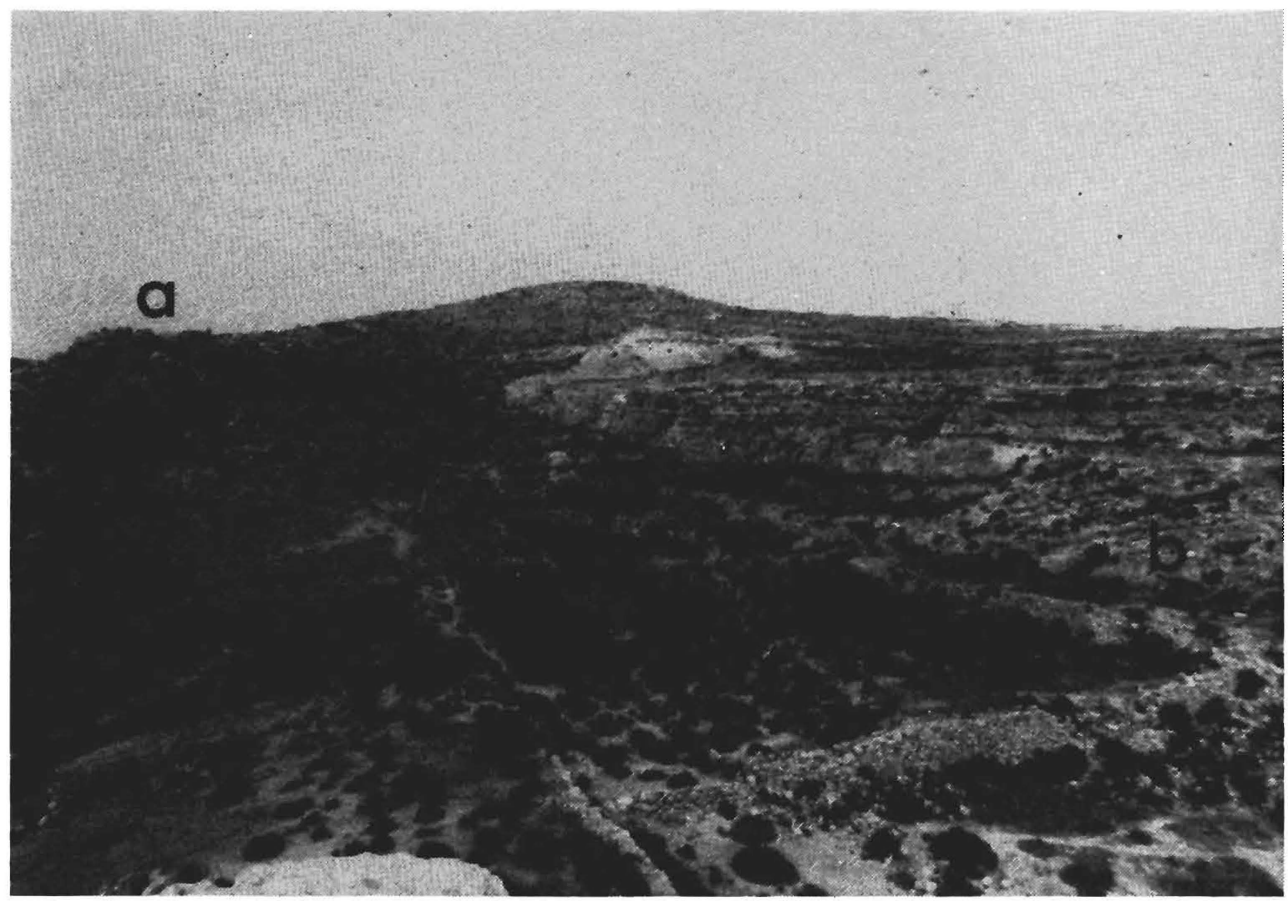

Fig. 10. Feather-within-feather structure showing vertical tilt-block rotation (a) and isolated arbitrary tilted blocks (b) due to the opening and the intersection of the faults.

and Illies $(1980,1981)$ attributed their formation, according to Laughton \& Whitmarsh (1974), to a period of sinistral shear motion parallel to the plate boundary which ended about 10 million years ago. During the Tortonian, Tunisia was affected by an important tectonic phase and at the same time the graben structures in the Strait of Sicily appeared (Burollet \& Byramjee 1974). This is very well recognized on Malta in $150^{\circ}$ trending synsedimentary normal faults in the middle Upper Coralline Limestone. On Lampedusa a synsedimentary fault and fracture zone of about the same trend is observable. The sediments of Lampedusa correspond also to the middle Upper Miocene up to Tortonian (Serge 1964, Colantoni \& Borsetti 1973). The northwards directed motion of the African plate against the European plate had induced a stress field that reactivated NNW-SSE trending fault zones which had been already traced out during Late Cretaceous and Eocene times. The preexisting pattern in the subjacent beds of the Maltese Islands, which is supposed by Vossmerbäumer (1972) to be responsible for the NNW-SSE trend in the joint pattern should have been caused by the same stress field.

The predominant structures on Malta are NE-SW trending horsts and grabens which cut through the entire Tertiary rock succession. These dip slip movements took place between Tortonian-Lower Messinian and Quaternary times. At the same time the NW-SE trending Pantelleria Rift System started to evolve. Some of the NE-SW striking faults traversing Malta are hinge faults with an increase of vertical displacement towards the $\mathrm{W}$ on to the Panelleria Rift. This might be due to the simultaneous temporary tectonic activity of both graben systems, caused by an updoming mantle leading to regional uplift. From southern Sicily towards Pantelleria the crustal 


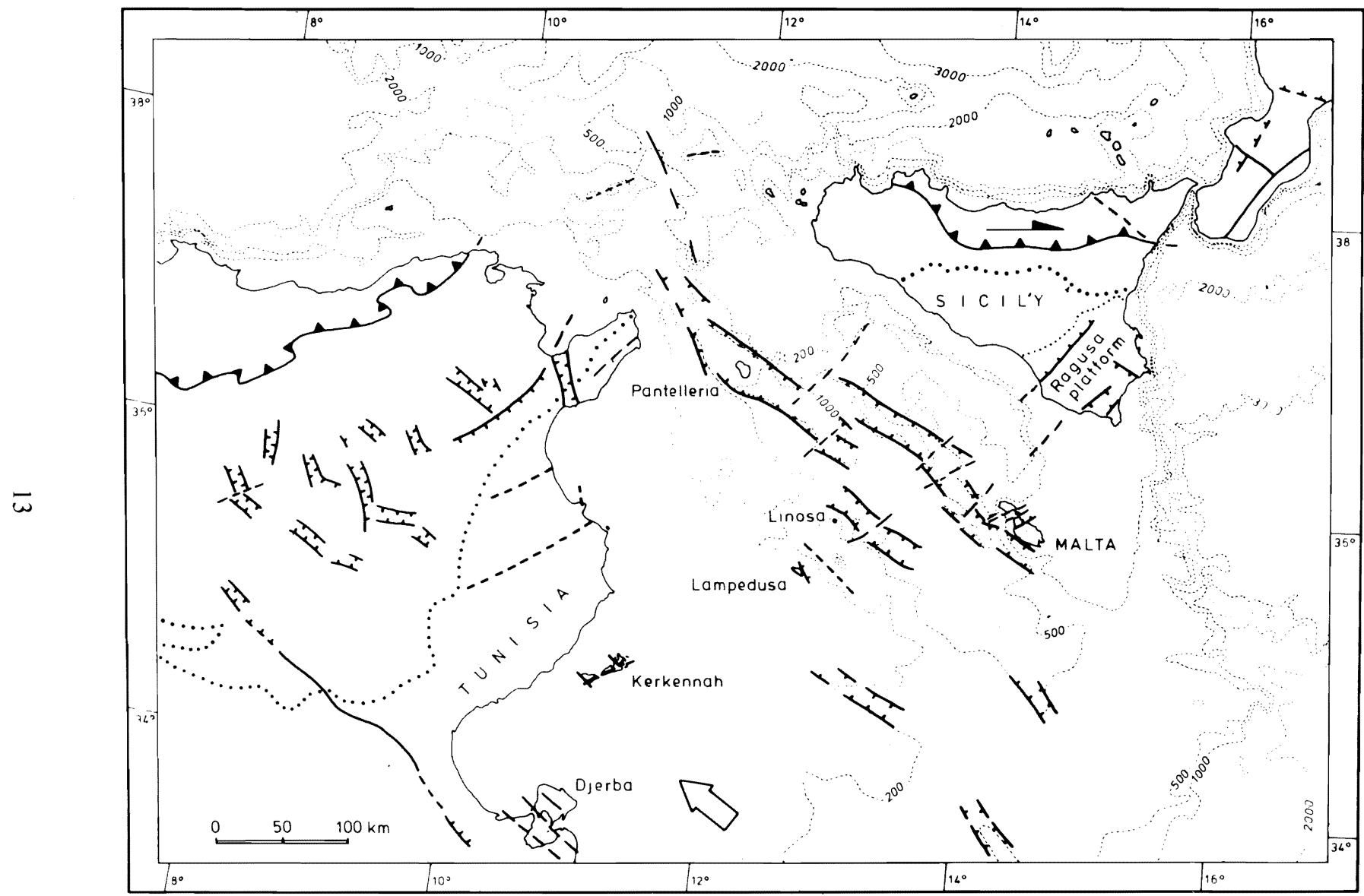

Main Alpine

collision tront

-... Front of externides

and foreland folding

1. Graben of late Miocene

to Recent activity

$\vec{D}$ relative plate motions

Fig. 11. Structures of the Central Mediterranean Region (compiled after Carte Tect. Int. de l'Europe, Moscow 1964, Burollet 1971 \& 1978, Ghisetti \& Vezzani 1981, Illies 1981). The Pantelleria Rift System traverses the shelf between Northern Africa and Sicily. The tectonic pattern is governed by the interaction and superimposition of different stress regimes due to the convergent and lateral plate motions between Africa and Europe. 
thickness decreases from over $30 \mathrm{~km}$ to $21-20 \mathrm{~km}$ (Colombi et al. 1973, Fig. 1).

The NW-SE staggered arranged individual fault troughs of the Pantelleria Rift System foundered mostly during Pliocene and basalt injections along the faults widened additionally the grabens (Morelli et al. 1975). The unloading of the Upper Mantle caused subsequent density reduction and upbulging (Illies 1981).

The upwarped shoulders of the rift are mostly shallow banks and rise above sea level with the Pelagian Islands of Lampedusa and Lampione on the western shoulder and the Maltese Islands on the eastern shoulder. Due to this shoulder upwarping the Maltese Islands are tilting towards NE. Post Quarternary tilting is indicated on northern Malta (Vossmerbäumer 1972). Quarternary beds are inclined up to $3^{\circ}$ to the NE.

The study of the recent stress field around the Pantelleria Rift System has been started by a group of the Geologisches Institut, Universität Karlsruhe, in 1983. First results of in-situ stress measurements show an actual direction of maximum horizontal compression between $115^{\circ}$ and $125^{\circ}$ (pers. com. Dipl.-Geol. V. Bräuer). The sites of stress measurements are located on the northern coast of Malta in the Lower Coralline Limestone Formation.

However the same faults bordering the different grabens of the Pantelleria System have been also affected by slight horizontal movements. Staggered arranged feather joints in the late Quaternary Green Tuff on the northern coast of Pantelleria Island can be related to dextral horizontal shear motions trending $130^{\circ}$. This fits the model of Illies $(1980,1981)$ of extensional en echelon faulting of the graben segments in the sense of second order faulting related to a dextral compressional megashear parallel to the Mediterranean plate boundary (Illies 1980, 1981). Convergent and lateral plate motions characterize the Afro-Eurasian plate boundary (Caire 1978, Ghisetti \& Vezzani 1981, Udias 1980, 1982). The two superimposing processes induce different stress regimes in which due to some blockage of the northeastern edge of the African plate either compressional stress or shear stress activates or reactivates the fault pattern (Fig. 11).

\section{ACKNOWLEDGEMENTS}

The structural investigations in Malta have been financially supported by the DEUTSCHE FORSCHUNGSGEMEINSCHAFT, SONDERFORSCHUNGSBEREICH 108 (Teilprojekt C1), Universität Karlsruhe, Contribution No. 54. I thank Dipl. Geol. V. Bräuer who carried out the in-situ stress measurements on Malta. I am very grateful to Mr. Lawrence Ellul, Professor C. J. Camilleri and Miss Pauline Farrugia, M.Sc., University of Malta, for supporting the project in Malta. Many thanks are due to Dr. George Zammit-Maempel for introducing me to the Maltese stratigraphy and for his kind hospitality during my stays in Malta.

\section{REFERENCES}

Barberi, F., Civetta, L., Gasparini, P., Innocenti, F., Scandone, R. and Villari, L. (1974) Evolution of a section of the Africa-Europe plate boundary: palaeo-magnetic and volcanological evidence from Sicily. Earth and Planetary Science Letters 22:123-132.

Bosence, D. W. J. and Pedley, H. M. (1982) Sedimentology and palaeoecology of a Miocene coralline algal biostrome from the Maltese islands. Palaeogeogr., Palaeoclimatol., Palaeoecol. 39:9-43 
B. P. Exploration Company Ltd. (1957) Geological survey of the Maltese islands. Scale 1:31680, 2 sheets.

Burollet, P. F. (1971) La Tunisie (Tectonique de l'Afrique, UNESCO) Science de la Terre 6:91100

Burollet, P. F. (1978) Mouvements quaternaires et récents aux iles Kerkennah (Tunisie orientale). C. R. Acad. Sc. Paris 286, Ser. D: 1133-1136.

Burollet, P. F. and Byramjee, R. S. (1974) Réflexions sur la tectonique globale exemples Africains et Méditerranéens. Comp. Francaise des Petroles, Notes \& Memoires 11:71-120.

Burollet, P. F., Mugniot, J. M. and Sweeney, P. (1978) The geology of the Pelagian block: the margins and basins off southern Tunisia and Tripolitania. In: A. E. M. Nairn, W. H. Kanes and F. G. Stehli (editors), The ocean basins and margins 4B, New York: Plenum Press, pp. $331-359$.

Carte Tectonique Int. de l'Europe (1964). Scale 1:2500000, Moscow.

Caire, A. (1978) The Central Mediterranean mountain chains in the Alpine orogenic environment. In: A. E. M. Nairn, W. H. Kanes and F. G. Stehli (editors), The ocean basins and margins 4B, New York:Plenum Press, pp. 201-256.

Colantoni, P. and Borsetti, A. M. (1973). Some notes on the geology and stratigraphy of the Strait of Sicily. Rapp. et proces-verbaux, Reunion Comm. Int. Expl. Scient. Mer Mediterr. 22:70-72.

Colombi, B., Giese, P., Luongo, G., Morelli, C., Scarascia, S., Schütte, K.-G., Strowald, J. and Visentini, G. (1973) Preliminary report on the seismic refraction profile Gargano-SalernoPalermo-Pantelleria (1971). Bull. Geol. Soc. Greece 10(1):39-42.

Di Geronimo, I., Grasso, M. and Pedley, A. M. (1981) Palaeoenvironment and palaeogeography of Miocene marls from southeast Sicily and the Maltese islands. Palaeogeogr., Palaeoclimatol., Palaeoecol. 34:173-189.

Felix, R. (1973) Oligo-Miocene stratigraphy of Malta and Gozo. Meded. Landbouwhogesch. Wageningen, Neder. 73(20):1-103.

Finetti, I. (1982) Structure, stratigraphy and evolution of the Central Mediterranean. Boll. Geofis. Teor. Appl. 24(96):247-312.

Finetti, I. and Morelli, C. (1973) Geophysical exploration of the Mediterranean Sea. Boll. Geofis. Teor. Appl. 15(60):263-344.

Ghisetti, F. and Vezzani, L. (1981) Contribution of structural analysis to understanding the geodynamic evolution of the Calabrian arc, Southern Italy. J. Structural Geol. 3(4):371-381.

Giannelli, L. and Salvatorini, G. (1975) I foramnifera planktonici dei sedimenti tertiari dell'archipelago maltese II. Biostratigrafia di Blue Clay, Greensand e Upper Coralline limestone. Mem. Atti Soc. Tosc. Sci. Nat. ser.A 83:1-24.

Hobbs, W. H. (1914) The Maltese islands: a tectonic topographic study. Scot. Geogr. Mag. 30:113.

House, M. R., Dunham, K. C. and Wigglesworth, J. C. (1961) Geology of the Maltese islands. In: H. Bowen-Jones, I. C. Dewdeney and W. B. Fisher (editors), Malta:Background for developement, Durham:University of Durham Press, pp. 24-33.

Hyde, H. P. T. (1955) Geology of the Maltese islands. Malta:Lux, $135 \mathrm{pp}$.

Illies, J. H. (1980) Form and formation of graben structures: the Maltese islands. In: H. Closs, K. v. Gehlen, H. Illies, E. Kuntz, J. Neumann and E. Seibold (editors), Mobile Earth, Boppard:Boldt, pp. 161-184.

Illies, J. H. (1981) Graben formation - the Maltese islands - a case history. Tectonophysics 73:151-168.

Laughton, A. S. and Whitmarsh, R. B. (1974) The Azores-Gibraltar plate boundary. In: L. Kristjansson (editor), Geodynamics of Iceland and the North Atlantic area, Dordrecht:Reidel, pp. 63-81.

Letouzey, J. and Trémolières, P. (1980) Palaeo-stress field around the Mediterranean since the Mesozoic from microtectonics. Comparisons with plate tectonic data. Rock Mechanics, Suppl. 9:173-192.

McKenzie, D. P. (1970) Plate Tectonics of the Mediterranean region. Nature 226:239-243. 
McKenzie, D. P. (1972) Active tectonics of the Mediterranean region. Geophys. J. R. Astr. Soc. 30:109-185.

Morelli, C., Gantar, P. and Pisani, M. (1975) Bathymetry, gravity and magnetism in the Strait of Sicily and in the Ionian Sea. Boll. Geofis. Teor. Appl. 17(65):39-58.

Murray, J. (1890) The Maltese islands with special reference to their geological structure. Geograph. Mag. 6:449-488.

Pedley, H. M. (1974) Miocene sea-floor subsidence and later subaerial subsidence structures in the Maltese islands. Proc. Geol. Ass. 85:533-547.

Pedley, H. M. (1978) A new lithostratigraphical and palaeoenvironmental interpretation for the coralline limestone formations (Miocene) of the Maltese islands. Overseas Geology Mineral Resources 54:1-17.

Pedley, H. M. (1983) The petrology and palaeoenvironment of the Sortino group (Miocene) of S. E. Sicily: evidence for periodic emergence. J. Geol. Soc. London 140:335-350.

Pedley, H. M. and Waugh, B. (1976) Easter field meeting to the Maltese islands. Proc. Geol. Ass. 87:325-341.

Pedley, H. M., House, M. R. and Waugh, B. (1976) The geology of Malta and Gozo. Proc. Geol. Ass. 87:325-341.

Pedley, H. M., House, M. R. and Waugh, B. (1978) The geology of the Pelagian block: The Maltese islands. In: A. E. M. Nairn, W. H. Kanes and F. G. Stehli (editors), The ocean basins and margins, 4B, New York:Plenum Press, pp. 201-256.

Reuther, C.-D. (1983a) Neotectonic pattern and processes on the Maltese islands caused by the Pantelleria Rift - Central Mediterranean Sea. Terru Cognita 3(2-3):87-88.

Reuther, C.-D. (1983b) Muster und Mechanismen der Bruchstrukturen auf den Maltesischen Inseln - Nordostschulter des Pantelleria Rifts. Berichtsband 1981-1983:405-428 (Sonderforschungsbereich 108, Universität Karlsruhe).

Reuther, C.-D. (1983c) Muster und Mechanismen dextraler Riedelscherung. Oberrhein. geol. Abh. 32:5-14.

Riedel, W. (1929) Zur Mechanik geologischer Brucherscheinungen. Centralalbl. Min. Geol. u. Pal. 1929B:354-368.

Segre, A. G. (1960) Geologia. In: E. Zavattari (editor), Biogeografia delle isole Pelagie. Academia Nazionale dei XL, Rendiconti, ser. IV 11:115-162.

Smith, A. G. (1971) Alpine deformation and the oceanic areas of the Tethys, Mediterranean and Atlantic. Bull. Geol. Soc. Am. 82:2039-2070.

Smith, A. G. and Woodcock, N. A. (1982) Tectonic syntheses of the Alpine-Mediterranean region: a review. In: H. Berckhemer \& K. Hsü (editors), Alpine-Mediterranean Geodynamics: Geod. Ser. 7, Washington D.C., pp. 15--38.

Spratt, T. A. B. (1954) Geology of Malta and Gozo. Malta, 16pp.

Trechmann, C. T. (1938) Quaternary conditions in Malta. Geol. Mag. 75:1-26.

Udias, A. (1980) Seismic stresses in the region Azores - Spain - Western Mediterranean. Rock Mech., Suppl. 9:173-192.

Udias, A. (1982) Seismicity and seismotectonic stress field in the Alpine Mediterranean region. In: H. Berckhemer and K. Hsü (editors), Alpine-Mediterranean geodynamics, Geod. Ser., 7, Washington D.C., pp. 75-82.

Vossmerbäumer, H. (1972) Malta, ein Beitrag zur Geologie und Geomorphologie des Zentralmediterranean Raumes. Wurzburger Geograph. Arb. 38:1-213.

Zammit-Maempel, G. (1977) An outline of Maltese geology. Malta, 44 pp. 